\title{
Comparative Effect of Zinc Concentration and Sources on Growth Performance, Accumulation in Tissues, Tibia Status, Mineral Excretion and Immunity of Broiler Chickens
}

-Author(s)

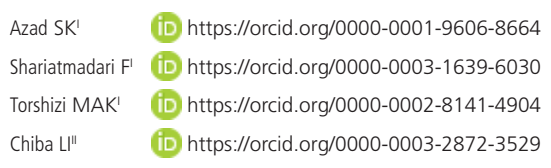

Department of Animal Science, Faculty of agriculture, Tarbiat Modares University, 14115336. Tehran, Iran.

" Dept. of Animal Science, Auburn University, Auburn, AL, United States.

\section{-Mail Address}

Corresponding author e-mail address Farid Shariatmadari

AB Vista Asia Pte Ltd, Singapore, Singapore 329682 - Singapore.

Phone: +65 90050526

Email: shariatf@modares.ac.ir

\section{-Keywords}

Broiler chickens, growth performance, bone characteristic, immunity, Zinc.

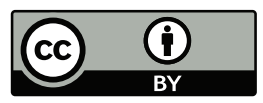

Submitted: 25/December/2019

Approved: 27/February/2020

\section{ABSTRACT}

This experiment was conducted to investigate the effect of feeding different concentrations and sources of zinc (Zn) on the growth performance, tissue mineral status, bone morphology and immunity responses in 0-4-week broiler chickens. Four hundred and forty 1-d-old broiler chickens were assigned randomly to 11 dietary treatments with 4 cages per treatment and 10 broiler chickens per cage in a completely randomized design. Dietary treatments were: corn-soybean meal basal diet (negative control), basal diet supplemented with $5 \mathrm{~g}$ yeast $/ \mathrm{kg}$ (yeast), and basal diet supplemented with 20,50 , or $80 \mathrm{mg}$ of added $\mathrm{Zn} / \mathrm{kg}$ as ZnSO4, Zn-Met, or Zn-yeast in a $3 \times 3$ factorial arrangement of treatments. The results showed that broilers fed $Z n$ supplemented diets had greater average weight gain and average feed intake than chickens fed the negative control diet $(p<0.05)$. The $\mathrm{Zn}$ deposition in tibia, meat (thigh and breast) and excreta increased $(p<0.01)$, regardless of source, in response to increasing dietary Zn concentrations. Zinc level increased dry weight of tibia bone and its large diameter. The strength of tibia bone as judged by Seedor index and breaking strength was improved $(p<0.01)$ with $\mathrm{Zn}$ concentration in increased diets. Furthermore, supplemental $\mathrm{Zn}$ up to $50 \mathrm{mg} / \mathrm{kg}$ improved immunity responses of broiler chickens $(p<0.01)$. It is concluded that supplementation with 50 mg Zn may be sufficient for normal broiler growth up to $28 \mathrm{~d}$ of age and the dietary inclusion of organic $Z n$ could be utilized more effectively when compared to inorganic sources.

\section{INTRODUCTION}

Zinc is an essential trace element that acts as a cofactor in many metabolic pathways including cell proliferation, growth, skeletal development, immune system, reproduction, hormone secretion, and antioxidant defense system, as well as many biochemical processes Swiatkiewicz et al., 2001; Ao et al., 2011; Tomaszewska et al., 2017; Muszyński et al., 2018). Thus, it is critical to use an optimal supplementation inclusion rate of $\mathrm{Zn}$ to allow poultry to reach their genetic potential and performance. The National Research Council (NRC 1994) recommended the minimum levels of $35 \mathrm{mg} / \mathrm{kg}$ in the diet that are necessary for optimum productivity for young broiler chickens. It has been reported that $71 \pm 13 \mathrm{mg} \mathrm{Zn/g}$ in a maize-soybean meal basal diet was necessary to maximize growth in broilers from hatch to $21 \mathrm{~d}$ of age (Huang et al., 2007). However, natural Zn concentrations in common feedstuffs are generally lower than the daily $\mathrm{Zn}$ requirement for poultry, leading to the necessity of dietary Zn supplementation. In practice, food manufacturers and producers formulate diets to contain 100-120 mg supplemental Zn/kg (Shyam Sunder et al., 2008; Feng et al., 2010). On the other hand high dietary Zn supplementation in diet may affect the balance of other trace elements (Abedini et al.,2017), and 
Comparative Effect of Zinc Concentration and Sources on Growth Performance, Accumulation in Tissues, Tibia Status, Mineral Excretion and Immunity of Broiler Chickens causes toxicity (Carl et al.,2003). High Zn consumption could also lead to increased excretion of $\mathrm{Zn}$ in feces, which causes environmental contamination (Pierce et al., 2005).

Research shows that the bioavailability of trace minerals in inorganic forms is low in poultry carcass (Cao et al., 2002). Therefore, enhancement of $\mathrm{Zn}$ bioavailability using more available sources can help to solve such problems. As such, organic mineral sources such as proteinate and amino acid chelates have been increasingly used in recent years because of their greater bioavailability and less excretion (Pierce et al., 2005). Previous studies have shown that the effect of different mineral sources, organic or inorganic, varies on production performance (Schlegel et al., 2013; Sahoo et al., 2014; Badawi et al., 2017). While in many studies, organically bound Zn has been demonstrated to have greater relative bioavailability than that of inorganic forms (Wedekind et al., 1992; Cao et al., 2000), others have seen no differences in bioavailability among organic and inorganic Zn sources (Hudson et al., 2004; Zakaria et al., 2017).

To our knowledge, the bioavailability of Zn-enriched yeast has not been previously fully elucidated and no comparative study (between this form and other organic and/or inorganic forms) has been carried out in broilers. Thus, the other objectives of the present study were to examine the effects of dietary supplementing different concentrations of $\mathrm{Zn}$ from various sources on growth performance, $Z n$ excretion, leg development and immune responses in broiler chickens.

\section{MATERIALS AND METHODS}

\section{Birds, diets, and experimental design}

The experimental protocol was approved by the animal-welfare committee of Tarbiat Modares University, and the animals were handled and treated in a humane manner.

Four hundred and forty 1-day-old broiler chickens (Ross 308) were assigned randomly to 1 dietary treatment group consisting of 4 replicates of 10 broilers in a completely randomized design arrangement of treatments. The house for the broilers was provided with programmed lighting and ventilation. Ambient temperature was gradually decreased from $32^{\circ} \mathrm{C}$ on day 1 to $22^{\circ} \mathrm{C}$ by the end of the experiment. Broilers were allowed ad libitum access to experimental diets and tap water containing no detectable Zn $(<0.001$ $\mathrm{mg} / \mathrm{L})$. Also, feed and water were provided using plastic instruments to minimize environmental $\mathrm{Zn}$ contamination.

The basal corn-soybean meal diets (Table 1), which was fed in mash form, were formulated to meet or exceed the NRC (1994) requirements for starter and grower broilers except for Zn. Dietary treatments included the un-supplemented basal diet with $\mathrm{Zn}$ (control), and supplemented with 20,50, or $80 \mathrm{mg}$ of $\mathrm{Zn} / \mathrm{kg}$ as feed-grade $\mathrm{Zn}$ sulfate $\left(\mathrm{ZnSO}_{4} \cdot 7 \mathrm{H}_{2} \mathrm{O}\right), \mathrm{Zn}$ Methionine (Bioplex Zinc; Alltech, Inc) and Zn-enriched yeast (that was produced on a laboratory scale as described by Kamran Azad et al 2014). All of the diets were calculated to contain equal concentrations of methionine. The background $\mathrm{Zn}$ concentration of the control diets were 24.4 and $21.6 \mathrm{mg} / \mathrm{kg}$, in the starter and grower diets, respectively (Table 1 ).

Table 1 - Ingredient and nutrient composition of the basal diets.

\begin{tabular}{lcc}
\hline $\begin{array}{l}\text { Ingredients }(\%) \\
\text { (Basal Diet) }\end{array}$ & $\begin{array}{c}\text { Composition Starter phase } \\
(1-14 \mathrm{~d})\end{array}$ & $\begin{array}{c}\text { Grower phase } \\
(15-28 \mathrm{~d})\end{array}$ \\
Maize & 57.5 & 62.1 \\
Soy-bean meal & 32.3 & 26.7 \\
Maize gluten meal & 4.4 & 4.5 \\
Vegetable oil & 2.1 & 3.5 \\
Dicalcium phosphate & 1.7 & 1.3 \\
Oyster shell & 1.1 & 1.1 \\
Sodium chloride & 0.3 & 0.2 \\
Vitamin-mineral premix & 0.5 & 0.5 \\
L-Lysine.H & 0.1 & 0.1 \\
\hline Calculated values ${ }^{2}$ & & \\
(as fed basis) & & 3150 \\
\hline AME $(\mathrm{kcal} / \mathrm{kg})$ & 3000 & 200 \\
\hline Protein $(\mathrm{g} / \mathrm{Kg})$ & 220 & 8.0 \\
Ca (g/Kg) & 8.9 & 4.0 \\
\hline Nonphytate P $(\mathrm{g} / \mathrm{Kg})$ & 4.8 & 21.6 \\
\hline Zn (mg/kg) & 24.4 & \\
\hline
\end{tabular}

Vitamin premix provided per kilogram of diet: vitamin A, 7,040 IU; vitamin D3, 2,000 $\mathrm{IU}$; vitamin $\mathrm{E}, 8.8 \mathrm{IU}$; vitamin $\mathrm{K} 3,1.76 \mathrm{mg}$; biotin, $0.12 \mathrm{mg}$; thiamine, $1.2 \mathrm{mg}$; riboflavin, $3.2 \mathrm{mg}$; pantothenic acid, $6.4 \mathrm{mg}$; pyridoxine, $1.97 \mathrm{mg}$; niacin, $28 \mathrm{mg}$; vitamin B12, $0.008 \mathrm{mg}$; choline, $320 \mathrm{mg}$; folic acid, $0.38 \mathrm{mg}$. Mineral premix provided per kilogram of diet: $\mathrm{Mn}, 60 \mathrm{mg}(\mathrm{MnO}) ; \mathrm{Fe}, 60 \mathrm{mg}\left(\mathrm{FeSO}_{4} \cdot 7 \mathrm{H}_{2} \mathrm{O} ; \mathrm{Cu}, 4.8 \mathrm{mg}\left(\mathrm{CuSO}_{4} \cdot 5 \mathrm{H}_{2} \mathrm{O}\right)\right.$; I, $0.69 \mathrm{mg} ; \mathrm{Se}, 0.16 \mathrm{mg}\left(\mathrm{Na}_{2} \mathrm{SeO}_{3}\right) ; \mathrm{Zn}, 0 \mathrm{mg}$.

The values were calculated from NRC (1994).

The yeast contained $39.9 \%$ of protein, almost 6897 $\mathrm{KJ} / \mathrm{kg}$ of metabolizable energy and $11.3 \mathrm{mg} \mathrm{Zn} / \mathrm{g}$. Moreover, the amount of accumulated organically bound $\mathrm{Zn}$ in yeast biomass was $87 \%$ of the total $\mathrm{Zn}$ in the cell. The dietary concentration of $\mathrm{Zn}$ for $\mathrm{Zn}$ sulfate (42.1, 69.3 and 103.6), Zn methionine (46.2, 71.0, $104.5)$ and Zn-enriched yeast $(48.3,70,8,101.4)$ were respectively at inclusion levels of 20,50 and 80 (mg/ $\mathrm{kg})$

The experiment lasted 28 days. Body weight of all broilers and feed consumption of each group were 
Azad SK, Shariatmadari F, Torshizi MAK, Chiba LI
Comparative Effect of Zinc Concentration and Sources on Growth Performance, Accumulation in Tissues, Tibia Status, Mineral Excretion and Immunity of Broiler Chickens recorded at weekly intervals, starting from one day of age. Growth performance was evaluated in terms of average weight gain (AWG), average feed intake $(\mathrm{AFI})$ and feed conversion ratio (FCR) at the end of each feeding period.

\section{Sample collection and measurements}

On d 28 of the experiment, 2 broilers from each replicate cage ( 8 broilers per treatment) were randomly selected within the cage following a 6-h fast, weighed individually, and were then killed.

\section{Chemical analysis}

Zinc concentrations in Zn sources, diets, tap water and tissues were determined by flame atomic absorption spectrophotometry (Model Avanta S, Atomic Absorption, GBC, Sydney, NSW, Australia) after wet digestions, as described by Sandoval et al. (1998). Briefly, samples of tissues and diets were dried at $105^{\circ} \mathrm{C}$ for $12 \mathrm{~h}$. Tissues were predigested in $\mathrm{HNO}_{3^{\prime}}$ till charring was completed, then all samples were ashed dry at $550{ }^{\circ} \mathrm{C}$ for $12 \mathrm{~h}$, solubilized in $\mathrm{HCl}$, and filtered through 42 Whatman paper.

The right tibia was removed and cleaned of the soft tissue before the bone was dried at $105^{\circ} \mathrm{C}$ for a minimum of $24 \mathrm{~h}$. After $72 \mathrm{~h}$-extraction in diethyl ether, the bone was dried for $12 \mathrm{~h}$ at $105^{\circ} \mathrm{C}$ and ashed at $550^{\circ} \mathrm{C}$ overnight in a muffle furnace (Yuan et al. 2011). Charred bones were digested as described before. The bone outer dimensions were measured by a digital caliper (Mitutoyo, Mizonokuchi Co, Utsonomiya, Japan). These bone parameters were measured on un-dried tibia samples. For determination of ash, the bones were placed in the oven for $24 \mathrm{~h}$ at $105{ }^{\circ} \mathrm{C}$ to dry completely and weighed. After that, the bones were ashed $\left(650{ }^{\circ} \mathrm{C}\right.$ for $\left.14 \mathrm{~h}\right)$ and the ash weight was recorded. The material obtained from 2 duplicate was pooled.

For bone mechanical and geometric properties character, the following measurements were conducted. The Seedor index is the value obtained when the bone weight is divided by its length, as proposed by Seedor et al. (1991). It is used as a bone density indicator, the higher the value the denser the bone. Bone breaking strength was determined by material testing machine (Model H50KS; Hounsfield Co, London, England). The robusticity indexes were determined using the following formulas (Reisenfeld, 1972).

Robusticity index = bone length / cube root of bone weight
To collect the excreta, 2 birds from each replicate were placed in a cage. A polythene sheet was attached under the cages of the birds. Feed and feathers were carefully removed. The excreta were homogeneously mixed replicate-wise, representative samples of excreta were collected in a moisture cup and oven-dried at $105^{\circ} \mathrm{C}$ for $24 \mathrm{hr}$, and finely ground for mineral analysis as described previously.

\section{Immune response}

On the 14th and 21th day of the experimental period, 2 birds were selected from each group and intramuscularly injected with $2 \mathrm{ml}$ of $0.5 \%$ sheep red blood cell (SRBC). On the $21^{\text {st }}$ and $28^{\text {th }}$ day of the experiment, blood samples were collected and serum samples were used to measure humoral immunity. Antibody titre produced against haemagglutination was measured according to Peterson et al. (1999).

\section{Statistical analysis}

To test the effect of supplemented Zn, data were analysed using single degree of freedom contrast to compare all supplemental Zn treatment with the control treatment. Data were further analyzed by 2-way ANOVA (excluding control treatment) using the General Linear Model (GLM) procedure of SAS institute (SAS 2003). Replicate was considered as the experimental unit for all data. The model included main effects of supplemental Zn level, Zn source and their interaction. Influences regarding one ( $Z n$ level) of the main effects were based on irthohnal comparsion for linear response of dependent variables to independent variables. Duncan's multiple range tests was used to assess any significant differences at the probability level of $p \leq 0.05$ among the experimental treatments.

\section{RESULTS}

\section{Growth performance}

The broiler chickens fed diet without Zn supplementation had lower $(p<0.01)$ AWG and AFI than those fed zinc supplemented diets (Table 2). Similarly, in the entire 4-week period, AWG increased with the dietary $\mathrm{Zn}$ content $(p<0 \cdot 05)$, up to dietary concentration of $50 \mathrm{mg} \mathrm{Zn/kg}$. No additional response was observed at higher $\mathrm{Zn}$ concentrations. The inadequacy of $\mathrm{Zn}$ in the control diet depressed feed consumption $(p<0.05)$; so that the lowest feed intakes were attributed to un-supplemented groups and the highest $\mathrm{Fl}$ were shown in the 50 and $80 \mathrm{mg} / \mathrm{kg}$ of $\mathrm{Zn}$. Moreover, the main effect of $\mathrm{Zn}$ level was not 
Table 2 - Effects of Zn source and level on growth performance of broiler chicks ( 1 to $28 \mathrm{~d}$ ).

\begin{tabular}{|c|c|c|c|c|c|}
\hline Item $^{1}$ & Number of pens & Added Zn (mg/kg) & Weight gain $(\mathrm{g})$ & Feed consumption $(\mathrm{g})$ & FCR \\
\hline Control & 4 & 0 & 1165 & 2033 & 1.75 \\
\hline \multicolumn{6}{|l|}{ Main effect } \\
\hline \multicolumn{6}{|l|}{ Zn level $(\mathrm{mg} / \mathrm{Kg})$} \\
\hline & 12 & 20 & $1265^{b}$ & $2164^{b}$ & 1.71 \\
\hline & 12 & 50 & $1337^{a}$ & $2216^{a}$ & 1.66 \\
\hline & 12 & 80 & $1328^{a}$ & $2220^{a}$ & 1.67 \\
\hline \multicolumn{6}{|l|}{ Zn source } \\
\hline Zn sulfate & 12 & & 1261 & 2148 & 1.70 \\
\hline Zn- Methionine & 12 & & 1283 & 2169 & 1.69 \\
\hline Zn-enriched Yeast & 12 & & 1277 & 2157 & 1.69 \\
\hline Pooled SEM & & & 7.42 & 9.82 & 0.01 \\
\hline \multicolumn{6}{|l|}{ Source of variation } \\
\hline Zn level & & & $<0.001$ & 0.050 & 0.220 \\
\hline Zn source & & & 0.056 & 0.527 & 0.787 \\
\hline Zn level $\times$ source & & & 0.881 & 0.942 & 0.993 \\
\hline Control vs all supplemental Zn groups & & & 0.018 & $<0.001$ & 0.228 \\
\hline
\end{tabular}

a-b Means in the same column with no superscript letters after them or with a common superscript letter following them are not significantly different ( $p<0.05$ ).

${ }^{1}$ Mean values are based on data obtained from all $(n=10)$ chicks from each of the 4 replicate pens per treatment ( $n=40$ individual birds per treatment). Through analysis, a dummy variable was considered for the control and the three $\mathrm{Zn}$ sources so that the variable set to be zero for the birds not in the relevant group and one when they were in the relevant group.

significant for feed conversion ratio $(p<0.05)$. On the other hand the FCR was not affected with the dietary Zn sources but decreased with increasing Zn levels in both organic and inorganic groups.

\section{Tibia Zn concentration}

Zinc concentration in tibia was low in the broilers fed diets with no Zn supplementation (Table 3) but it increased in proportion to the dose of $\mathrm{Zn}$ supplementation to the basal diet and reached plateau at $50 \mathrm{mg} / \mathrm{kg}(p<0.01)$. Tibia $\mathrm{Zn}$ concentrations were also strongly related to the $\mathrm{Zn}$ source origin, as organically bound Zn significantly increased the $Z n$ content compared to inorganic supplementation $(p<0.05)$. There were small changes in tibia $\mathrm{Zn}$ when broiler chickens were fed on either $\mathrm{Zn}$-enriched yeast or commercial Zn methionine sources. The interaction between $\mathrm{Zn}$ level and its source was not significant for tibia Zn status.

\section{Zinc content of meat and excretion}

The $\mathrm{Zn}$ deposited in breast and thigh muscles reflected the level of dietary $\mathrm{Zn}$ (Table 3 ), the higher the inclusion level, the higher $\mathrm{Zn}$ content of muscles

Table 3 - Effects of dietary Zn source and level on tissue Zn content in 28-d-old broiler chicks.

\begin{tabular}{|c|c|c|c|c|c|c|}
\hline Item $^{1}$ & $\begin{array}{c}\text { Number of } \\
\text { pens }\end{array}$ & $\begin{array}{c}\text { Added Zn } \\
(\mathrm{mg} / \mathrm{kg})\end{array}$ & $\begin{array}{c}\text { Breast Zn content } \\
(\mu \mathrm{g} / \mathrm{g} D M)\end{array}$ & $\begin{array}{c}\text { Thigh Zn content } \\
(\mu \mathrm{g} / \mathrm{g} D M)\end{array}$ & $\begin{array}{c}\text { Breast Zn content } \\
(\mu \mathrm{g} / \mathrm{g} D M)\end{array}$ & $\begin{array}{c}\text { Excreta Zn content } \\
(\mu \mathrm{g} / \mathrm{g} \mathrm{DM})\end{array}$ \\
\hline Control & 4 & 0 & 162.1 & 22.5 & 3.91 & 175.6 \\
\hline \multicolumn{7}{|l|}{ Main effect } \\
\hline \multicolumn{7}{|l|}{ Zn level (mg/Kg) } \\
\hline & 12 & 20 & $234.9^{b}$ & $24.9^{b}$ & $4.90^{b}$ & $265.7^{c}$ \\
\hline & 12 & 50 & $276.7^{a}$ & $27.7^{a}$ & $5.15^{a}$ & $377.9^{b}$ \\
\hline & 12 & 80 & $276.3^{a}$ & $28.3^{a}$ & $5.23^{a}$ & $515.9^{a}$ \\
\hline \multicolumn{7}{|l|}{ Zn source } \\
\hline Zn sulfate & 12 & & $228.9^{b}$ & $24.9^{b}$ & 4.79 & 339.4 \\
\hline Zn- Methionine & 12 & & $241.2^{a}$ & $26.2^{a}$ & 4.82 & 332.5 \\
\hline Zn-enriched Yeast & 12 & & $242.3^{a}$ & $26.3^{a}$ & 4.83 & 332.5 \\
\hline Pooled SEM & & & 4.93 & 0.46 & 0.93 & 22.18 \\
\hline \multicolumn{7}{|l|}{ Source of variation } \\
\hline Zn level & & & $<0.001$ & $<0.001$ & $<0.001$ & $<0.001$ \\
\hline Zn source & & & 0.031 & 0.040 & 0.047 & 0.367 \\
\hline Zn level $\times$ source & & & 0.810 & 0.720 & 0.740 & 0.980 \\
\hline Control vs all supplemental Zn groups & & & $<0.001$ & $<0.001$ & $<0.001$ & $<0.001$ \\
\hline
\end{tabular}

${ }^{a-b}$ Means in the same column with no superscript letters after them or with a common superscript letter following them are not significantly different $(p<0.05)$.

1 There were 8 replicate consisting of samples taken from 2 birds per replicate (cage). 
$(p<0.01)$. Zn accumulation was more substantial in birds fed organically bound Zn supplemented diets relative to those fed inorganic $Z n$ counterpart $(p<0.01)$. Although the source of zinc affected the $Z n$ content of thigh meat, it did not influence the $\mathrm{Zn}$ content of breast. Zinc excretion increased nearly three folds $(p<0.01)$ from $175 \mathrm{ug} / \mathrm{g}(\mathrm{DM})$ control group to 515 $\mathrm{ug} / \mathrm{g}(\mathrm{DM})$ for $80 \mathrm{mg} / \mathrm{kg}$ zinc level $(p<0.01)$. There was no effect of zinc source on zinc excretion.

\section{Mechanical and geometric character of bone}

Mechanical and geometric characters of bones are presented in Table 4. Dry weight, Sidoor index, and breaking strength of tibia bone were affected by zinc content $(p<0.05)$. However, there was no further increase in these parameters beyond $50 \mathrm{mg} /$ $\mathrm{kg}$ zinc levels. The zinc source had no significant effect on mechanical and geometric characters of bone measured. There was no interaction between level and zinc source effect on any parameters measured.

\section{Immunity}

The dietary treatment had no effect on weight of bursa Fabricius while the spleen weight was increased as compared to the control group $(p<0.05)$. There was neither effect of zinc source nor interaction effect between zinc source and zinc level $(p<0.05)$ on the weights of bursa Fabricius and spleen (Table 5). Although there was no significant difference in preliminary antibody titer among all birds, the chicks that had received zinc supplementation had a higher secondary antibody titer as compared to the control $(p<0.05)$.

\section{DISCUSSION}

\section{Growth performance}

Zinc is an essential trace element for the normal function of numerous important structural proteins, enzymatic processes, lipid metabolism, hormone production and ultimately necessary for healthy growth and development of chicken. Inadequacy of Zn dosage in the bird diet reduces feed consumption and consequently body weight gain, but it could be reversed by $\mathrm{Zn}$ supplementation (Bao et al., 2007). Hudson et al. (2004) reported that different sources of $\mathrm{Zn}$ significantly affected body weight gain of broilers. Wedekind et al. (1992) studies indicated that the improvement in weight gain in broilers fed $\mathrm{Zn}$ supplemented diets may have resulted, in part, from increased consumption of basal diet, because anorexia

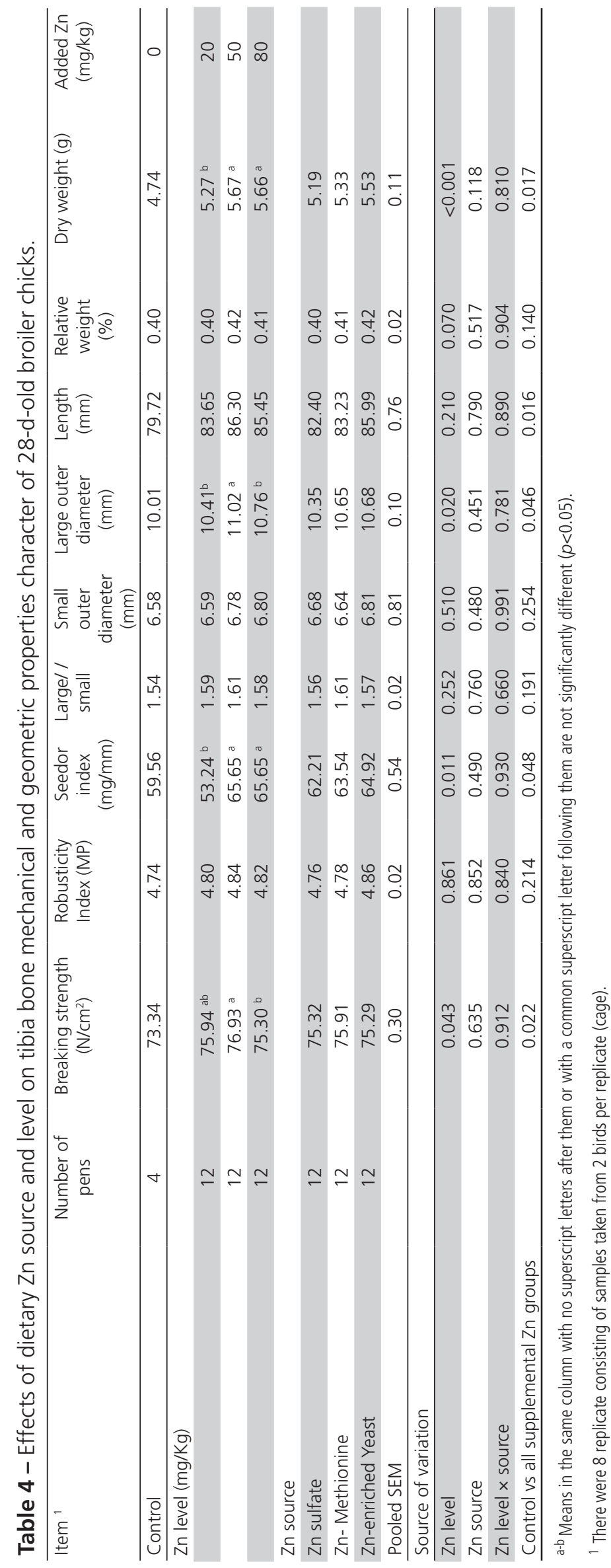


Table 5 - Effects of dietary Zn source and level on immune response of 28-d-old broiler chicks.

\begin{tabular}{|c|c|c|c|c|c|c|}
\hline \multirow[t]{2}{*}{ Item $^{1}$} & \multirow{2}{*}{$\begin{array}{c}\text { Number of } \\
\text { pens }\end{array}$} & \multirow[t]{2}{*}{ Added Zn (mg/kg) } & \multicolumn{2}{|c|}{ Relative weight (\%) } & \multicolumn{2}{|c|}{ Total Anti - SRBC ${ }^{1}$} \\
\hline & & & Bursa & Spleen & $\begin{array}{c}1^{\text {st }} \text { Response (day } \\
21 \text { ) }\end{array}$ & $\begin{array}{c}2^{\text {nd }} \text { response } \\
\text { (day 28) }\end{array}$ \\
\hline Control & 4 & 0 & 0.227 & 0.109 & 1.50 & 2.00 \\
\hline \multicolumn{7}{|l|}{ Main effect } \\
\hline \multicolumn{7}{|l|}{ Zn level (mg/ kg) } \\
\hline & 12 & 20 & 0.200 & 0.123 & 1.83 & $3.00^{\mathrm{b}}$ \\
\hline & 12 & 50 & 0.208 & 0.126 & 1.92 & $3.42^{\mathrm{a}}$ \\
\hline & 12 & 80 & 0.198 & 0.127 & 2.00 & $3.17^{\mathrm{b}}$ \\
\hline \multicolumn{7}{|l|}{ Zn source } \\
\hline Zn sulfate & 12 & & 0.211 & 0.120 & 1.81 & 2.75 \\
\hline Zn- Methionine & 12 & & 0.206 & 0.122 & 1.81 & 2.87 \\
\hline Zn-enriched Yeast & 12 & & 0.209 & 0.122 & 1.81 & 3.06 \\
\hline Pooled SEM & & & 0.009 & 0.008 & 0.031 & 0.050 \\
\hline Source of variation & & & & & $p$-value & \\
\hline Zn level & & & 0.150 & 0.311 & 0.146 & 0.033 \\
\hline Zn source & & & 0.121 & 0.016 & 0.415 & 0.785 \\
\hline Zn level $\times$ source & & & 0.862 & 0.981 & 0.912 & 0.818 \\
\hline Control vs all supplemental Zn groups & & & 0.092 & 0.017 & 0.011 & 0.008 \\
\hline
\end{tabular}

is the most common symptom of Zn deficiency, which led to the depressed growth of broilers. The mechanisms involved in the effects of Zn deficiency on growth are unknown, but a reduction in food consumption may be a protective reaction to allow survival (MacDonald, 2000). An explanation for increased body weight gain may be due to the positive effects of $\mathrm{Zn}$ methionine on digestion and absorption of nutrients in the gastrointestinal tract and/or to a higher bioavailability of $\mathrm{Zn}$ in the form of $\mathrm{Zn}$ methionine. On the other hand, refer to the participation of $\mathrm{Zn}$ in protein and carbohydrate metabolism, the reduction in feed intake associated with a lack of $\mathrm{Zn}$ (that could reduce feed digestibility), and consequently impaired performance parameters in broilers (Bao et al., 2007). These results are in agreement with Huang et al. (2007) who found Zn supplementation induced increase in feed intake and weight gain.

\section{Tibia Zn concentration}

Zinc is the most abundant trace element in bone, being present at a concentration of up to $300 \mathrm{mg} / \mathrm{kg}$ (Grynpas et al., 1987), and has been considered an important factor in bone metabolism. Not surprisingly, adequate $\mathrm{Zn}$ concentration is required for growth, development and mineralization of bone (Bao et al., 2003). Huang et al. (2009) demonstrated that the $\mathrm{Zn}$ content of the tibia was significantly influenced by dietary levels. Previous studies reported that feeding birds diets with a $\mathrm{Zn}$ concentration greater than $85 \mathrm{mg} / \mathrm{kg}$ did not influence tibia $\mathrm{Zn}$ deposition (Wedekind et al., 1992). However, in this study, tibia Zn concentrations increased with Zn supplementation only up to $50 \mathrm{mg} / \mathrm{kg}$ and there was no change at 80 $\mathrm{mg} / \mathrm{kg}$. Huang et al. (2007) indicated that bone status is commonly used as an indicator of mineral adequacy in poultry diets.

Also in agreement with the present study, other studies indicated that different sources of $\mathrm{Zn}$ supplementation affected the levels of $\mathrm{Zn}$ in tibia (Ao et al., 2011; Idowu et al., 2011). Moreover, many research studies (Cao et al., 2000; Huang et al., 2009; Ao et al., 2011) indicated that the dietary supplementation of organic $\mathrm{Zn}$ can result in greater accumulation of $\mathrm{Zn}$ in tibia than the same supplemental concentration of inorganic Zn.

According to Loveridge (1992) bone is a complex heterogeneous tissue that supports the musculature, and thus its growth and development are intimately connected with overall body growth and thus making tibia $\mathrm{Zn}$ concentration a good predictor of whole-body growth. This study indicates that using $50 \mathrm{mg} / \mathrm{kg} \mathrm{Zn}$ might meet the requirement for normal bone mineralization. In the present study, the same birds that obtained optimal body weight had highest tibia Zn. 
Azad SK, Shariatmadari F, Torshizi MAK, Chiba LI
Comparative Effect of Zinc Concentration and Sources on Growth Performance, Accumulation in Tissues, Tibia Status, Mineral Excretion and Immunity of Broiler Chickens

\section{Zinc content of meat and excretion}

Many researchers indicated that dietary $Z n$ level influence $\mathrm{Zn}$ content of nearly all types of tissues and organs (Park et al., 2004). The concept of "Functional foods", enriching poultry meat with different nutrients has attracted many researchers in recent decades (Peric et al., 2011). Our results though, indicate that $\mathrm{Zn}$ enrichment took place, the magnitude is not too high as compared to the control. The total $\mathrm{Zn}$ of thigh and breast meat in birds with no $\mathrm{Zn}$ addition is 26.4 $(\mu \mathrm{g} / \mathrm{g} D M)$ while the highest level of $\mathrm{Zn}$ inclusion (80) resulted to total $\mathrm{Zn}$ content of $30(\mu \mathrm{g} / \mathrm{g} \mathrm{DM})$.

On the other hand the magnitude of $\mathrm{Zn}$ excretion is nearly 2.5 folds; $176(\mu \mathrm{g} / \mathrm{g} D M)$ for no zinc added diet as compared to 515 for $80 \mathrm{mg} / \mathrm{kg}$ added Zn. This imbalance between the ability to enrich a product and/ or cause industrial pollution is of great importance to consider. This proves that there is a limit for enriching meat with zinc (like most other minerals) beyond which is depleted through excretion (Keen et al., 2003).

However, Bao et al. (2007) had shown organic minerals decreases minerals of excreta. Salim et al. (2010) indicated that chelated minerals (such as organic zinc) could resist interferences from dietary anti nutritional factors in the digestive tract and directly reach the intestinal brush border, where it is hydrolyzed and absorbed as an ion into to the blood, resulting in a greater availability.

\section{Mechanical and geometric character of bone}

This study suggests that using $50 \mathrm{mg} \mathrm{Zn/kg} \mathrm{(from}$ yeast $\mathrm{Zn}$ ) might meet the requirement for normal bone mineralization. Although Zn supplementation at specific levels is essential to optimize bone breaking resistance, it has been reported that higher levels of $\mathrm{Zn}$ in the diet appear to interfere with the absorption and utilization of $\mathrm{Ca}$ and $\mathrm{P}$, particularly above $80 \mathrm{ppm}$, and could decrease the bone mineralization (Underwood \& Suttle 1981) which was also observed in our study.

Many previously conducted studies show the negative impact of Zn deficiency on bone growth, and disorders that are associated with reduced activity of the growth plate (Brown et al., 1978). Scrimgeour et al. (2007) indicated that when $\mathrm{Zn}$ is not supplied sufficiently, proliferation, differentiation and survival of the bone cells are compromised. It seems that Zn, by increasing the number and activity of osteoblasts, leads to the deposition of calcium in the diaphysis of bones and increase mineralization in the tibia. Masayoshi and Hidetoshi (1989) demonstrated that $\mathrm{Zn}$ enhanced the effects of vitamin $D$ on bone metabolism by stimulating the synthesis of DNA in bone cells. On the other hand, Zn by stimulating bone metabolism and bone protein synthesis by increasing the activity of enzymes such as alkaline phosphatase, is involved in increasing bone mineralization and strength (Yamaguchi et al., 1988). It has also been suggested that $\mathrm{Zn}$ is involved in insulinlike growth factor I-(IGF-I) production that increases the collagen, DNA and bone matrix syntheses (Hock et al., 1988). Therefore, many effects of $\mathrm{Zn}$ on bone metabolism may be related to nucleic acid and protein metabolism.

\section{Immunity}

Since the spleen is the organ that is directly related to antibody production, it is expected that its weight be directly related to antibody production (Steiniger and Barth, 2000). While there are no concrete evidences as to the effect of zinc sources on weight of the brusa Fabricius and the spleen, there is not much dispute in regard to the effect of zinc levels on these organs. Yu et al. (2005) showed that diet lacking in zinc results to lower weight of the spleen. Increase of the weight of bursa (and not the spleen) in this study was similar with the result of Bartlett and Smith (2003), who showed a slight increase in the weight of lymphoid organs. Also, in their experiments on broilers reported that thymus, spleen, and bursa of Fabricius increased linearly with increasing dietary $\mathrm{Zn}$ (from $35 \mathrm{mg} / \mathrm{kg}$ to $68 \mathrm{mg} / \mathrm{kg}$ ). These findings could be due to the role of $\mathrm{Zn}$ in the growth and function of lymphocytes.

The results of this study indicated that $\mathrm{Zn}$ supplementation improves immune responses, as compared to the control. The immune system is dependent on the functions of cellular metabolism. $\mathrm{Zn}$ is ubiquitous in cellular metabolism and functions both structurally and catalytically in metalloenzymes (Bartlett \& Smith, 2003).

In this study the birds with higher spleen weight had higher SRBC secondary titer. However, the maximum secondary SRBC immune response was seen in birds receiving $50 \mathrm{mg} / \mathrm{kg}$ zinc $(p<0.05)$ but there was no differences with the $80 \mathrm{mg} / \mathrm{kg}$ level. In the other hand according to Sunder et al. (2008), humoral and cellmediated immune responses were significantly higher in broilers supplemented with $80 \mathrm{mg} / \mathrm{kg}$ or greater amounts of $\mathrm{Zn}$ than those supplemented with less than $80 \mathrm{mg} / \mathrm{kg}$ of Zn. Hudson et al. (2004) observed a higher cellular immune response to PHA and antibody titres against the Newcastle disease in broiler breeders fed with diets supplemented with organic sources of $Z n$, as compared to inorganic sources. Zinc is essential 
for thymulin, a thymic hormone that regulates $T$ lymphocyte maturation. Thus, birds fed with diets supplemented with a more available $\mathrm{Zn}$ source might have more thymulin activity and, therefore, promote immune responses through the increased maturation of T-lymphocytes and activation of B-lymphocytes by T-helper cells.

\section{CONCLUSION}

This experiment was conducted to examine the effect of different levels of zinc from different sources on broiler chickens performances. The levels were chosen to reflect the earlier proposed zinc requirement (NRC), recommended levels to present faster grower birds, and higher level than commonly practiced. As many earlier experiments to determine zinc requirement were done with inorganic zinc, it was presumed that organic zinc being more bioavailable will enhance the broiler performances at lower levels as compared to inorganic Zn. The main objective of our study apart from general performances criteria was to evaluate the effect of zinc on tissue and excretion zinc level and tibia morphology. According to our results, the optimal dietary $\mathrm{Zn}$ requirements for $0-4$-wk-old broilers were $50 \mathrm{mg} / \mathrm{kg}$ diet. Zinc level above $50 \mathrm{mg} / \mathrm{kg}$ not only did not improved performances criteria further, it adversely increased zinc excretion and ultimately environment pollution. Unlike many other studies, our results did not indicate that zinc sources (sulfate vs organic) within the range tested in this experiment had much influence on broiler performances.

\section{DISCLOSURE STATEMENT}

No potential conflict of interest was reported by authors.

\section{REFERENCES}

Abedini M, Shariatmadari F, Karimi Torshizim MA, Ahmadi H. Effects of a dietary supplementation with zinc oxide nanoparticles, compared to zinc oxide and zinc methionine, on performance, egg quality, and zinc status of laying hens. Livestock Science 2017;21:23-30.

Ao T, Pierce JL, Pescatore AJ, Cantor AH, Dawson KA, Ford MJ, et al. Effects of feeding different concentration and forms of zinc on the performance and tissue mineral status of broiler chicks. Brittish Poultry Science 2011;52:466-471.

Badawi M, Ali M, Behairy A. Effects of zinc sources supplementation on performance of broiler chickens. Journal of American Science 2017; 13:35-40

Bao YM, Choct M, lji PA. Bruerton K. Effect of organically complexed copper, iron, manganese, and zinc on broiler performance, mineral excretion, and accumulation in tissues. Journal of Applied Poultry Research 2007;16:448-455.
Bao YM, Choct M, lji PA, Bruerton K. Optimal dietary inclusion of organically complexed zinc for broiler chickens. Brittish Poultry Science 2003:50:95-102.

Bartlett JR, Smith MO. Effects of different levels of zinc on the performance and immunocompetence of broilers under heat stress. Poultry Science 2003;82:1580-1588.

Brown ED, Chan W, Smith JC. Bone mineralization during a developing zinc deficiency. Experimental Biology and Medicine 1978;157:211-214.

Carl L, Lynn AH, Louise LK, Clegg MS. Developmental consequences of trace mineral deficiences in rodents: acute and long-term effects. Journal of Nutrition 2003;15:1477S-80S.

Cao J, Henry PR, Davis SR, Cousins RJ, Miles RD, Littell RC, Ammerman CB. Relative bioavailability of organic zinc sources based on tissue zinc and metallothionein in chicks fed conventional dietary zinc concentrations. Animal Feed Science Technology 2002;101:161-170.

Cao J, Henry PR, Guo R. Chemical characteristics and relative bioavailability of supplemental organic zinc sources for poultry and ruminants. Journal of Animal Science 2000;78:2039-2054.

Feng J, Ma W, Niu H, Wu X, Wang Y. Effects of zinc glycine chelate on growth, hematological, and immunological characteristics in broilers. Biological Trace Element Research 2010;133:203-211.

Grynpas MD, Pritzker KPH, Hancock RG. Neutron activation of bulk and selected trace elements in bone using a low flux slowpoke reactor. Biological Trace Element Research 1987:13:333-344.

Hock JM, Centrella M, Canalis E. Insulin-like growth factor has independent effects on bone matrix formation and cell replication. Endocrinology $1988 ; 122: 254-260$

Huang YL, Lu L, Luo XG, Liu, B. An Optimal dietary zinc level of broiler chicks fed a corn-soybean meal diet. Poultry Science 2007;86:25822589 .

Huang YL, Lu L, Li SF, Luo XG, Liu, B. Relative bioavailabilities of organic zinc sources with different chelation stregths for broilers fed a conventional corn-soybean meal diet. Journal of Animal Science 2009;87(6):20382046.

Hudson BP, Dozier WA, Wilson JL, Sander JE. Ward TL. Reproductive Performance and immune status of caged broiler breder hens provided diets supplemented with either inorganic or organic sources of zinc from hatching to 65 wk of age. Journal of Applied Poultry Research 2004;13:349-359

Idowu, O, Ajuwon R, Oso A, Akinloye O. Effects of zinc supplementation on laying performance, serum chemistry and $\mathrm{Zn}$ residue in tibia bone, liver, excreta and egg shell of laying hens. International Journal of Poultry Science 2011;10:225-230.

Kamran Azad S, Shariatmadari F, Karimi Torshizi MA. Production of zincenriched biomass of Saccharomyces cerevisiae. Journal of Elementology 2014;19:313-326.

Keen CL, Hanna LA, Lanoue L, Uriu-Adams JY, Rucker RB, Clegg MS. Developmental consequences of trace mineral deficiencies in rodents: acute and long-term effects. Journal of Nutrition 2003; 133:14775-1480S.

Loveridge N. Micronutrients and longitudinal growth. Proceedings of the Nutrition Society 1992;52:49-55.

MacDonald RS. The role of zinc in growth and cell proliferation. Journal of Nutrition 2000;130:1500S-1508S.

Masayoshi, Y., Hidetoshi, O. Effect of 1, 25-dihydroxyvitamin D3 on bone metabolism in tissue culture: enhancement of the steroid effect by zinc. Biochemical Pharmacology 1989;38:3453-3459. 
Muszyński S, Tomaszewska E, Kwiecień M, Dobrowolski P, TomczykWarunek A. Subsequent somatic axis and bone tissue metabolism responses to a low-zinc diet with or without phytase inclusion in broiler chickens. PLoS One 2018;13:507-519.

NRC. Nutrient requirements of poultry. $9^{\text {th }}$ ed. Washington: National Academy Press; 1994.

Park SY, Birkhold GN, Kubena LF, Nisbet JR, Isvet RT, Ricke S. Review on the role of dietary zinc in poultry nutrition, immunity, and reproduction. Biological Trace Element Research. 2004;101:49-65.

Perić L, Rodić N, Milošević M. Production of poultry meat and eggs as functional food - chanlenges and opportunity. Biotechnology in Animal Husbandry.2011:27(3):511-520.

Peterson AL, Qureshi MA, Ferket PR, Fuller Jr JC. Enhancement of cellular and humoral immunity in young broilers by the dietary supplementation of $\beta$-hydroxy- $\beta$-methylbutyrate. Immmunopharmacology Immunotoxicology 1999;21:307-330.

Pierce J, Shafer B, Power R, Dawson K. Nutritional means to lower trace mineral excretion from poultry without compromising performance. Poultry Science 2005;84:11.

Reisenfeld, A. Metatarsal robusticity in bipedal rats. American Journal of Physical Anthropology 1972;40:229-234.

SAS Institute. SAS/STAT® user's guide: statistics version 6. Cary; 2003.

Sahoo A, Swain R, Mishra SK. Effect of inorganic, organic and nano Zn supplemented diets on bioavailability and immunity status of broilers. International Journal of Advanced Research 2014;11:828-837.

Salim HM, Lee HK, Jo C, Lee SK, Lee BD. Effect of sources and levels of zinc on the tissue mineral concentration and carcass quality of broilers. Avian Biology Research 2010;3:23-29.

Sandoval M, Henry PR, Luo XG, Littell RC, Miles RD, Ammerman CB. Performance and tissue zinc and metallothionein accumulation in chicks fed a high dietary level of zin. Poultry Science 1998:77:13541363.

Schlegel P, Sauvant D, Jondreville C. Bioavailability of zinc sources and their interaction with phytates in broilers and piglets. Animal 2013;7:47-59.

Scrimgeour AG, Stahl CH, McClung JP, Marchitelli LJ, Young AJ. Moderate zinc deficiency negatively affects biomechanical properties of rat tibiae independently of body composition. Journal of Nutrition Biochemistry 2007;18:813-819.

Seedor JG, Quarruccio HA, Thompson DD. The bisphosphonate alendronate (MK-217) inhibits bone loss due to ovariectomy in rats. Journal of Bone Mineral Research 1991;6:339-346.

Shyam Sunder G, Panda NC, Gopinath SV, Rama Rao MVL, Raju MR, Reddy TM, et al. Effects of higher levels of zinc supplementation on performance, mineral availability, and immune competence in broiler chickens. Journal of Applied Poultry Research 2008;17:79-86.
Steiniger B, Barth P. Function of splenic compartments. In: Beck F, Brown D, Christ B, Kriz W, Marani E, Putz R, editors. Advances in anatomy, embryology and cell biology. New York: Springer-Verlag, 2000. p.4564.

Sunder GS, Panda A, Gopinath N, Rao, SR, Raju M, Reddy M, et al. Effects of higher levels of zinc supplementation on performance, mineral availability, and immune competence in broiler chickens. Journal of Applied Poultry Research 2008;17:79-86.

Swiatkiewicz S, Koreleski J, Zhong DQ. The bioavailability of zinc from inorganic and organic sources in broiler chickens as affected by addition of phytase. Journal of Animal and feed Sciences 2001;10:317-328.

Tomaszewska El, Muszyński S, Dobrowolski P, Kwiecień M, WiniarskaMieczan A, Świetlicka Wawrzyniak A. Effect of Zinc level and source (zinc oxide vs. zinc glycine) on bone mechanical and geometric parameters, and histomorphology in male ross 308 broiler chicken. Brazilian Journal of Poultry Science 2017;19:159-170.

Tomaszewska El, Dobrowolski P, Kwiecień M, Wawrzyniak A, Burmanczuk $\mathrm{N}$. Comparison of the effect of a standard inclusion level of inorganic zinc to organic form at lowered level on bone development in growing male ross broiler chickens. Annual Animal Science 2017;16:507-519.

Underwood EJ, Suttle N. The mineral nutrition of livestock. London: CABI Publishing; 2001.

Wedekind KJ, Hortin AE, Baker DH. Methodology for assessing zinc bioavailability: efficacy estimates for zinc-methionine, zinc sulfate, and zinc oxide. Journal of Animal Science 1992;70:178-187.

Yamaguchi M, Oishi H, Suketa Y. Zinc stimulation of bone protein synthesis in tissue culture: activation of aminoacyl-tRNA synthetase. Biochemical Pharmacology 1988;37:4075-4080.

Yu ZP, Le GW, Shi YH. Effect of zinc sulphate and zinc methionine on growth, plasma growth hormone concentration, growth hormone receptor and insulin-like growth factor-I gene expression in mice. Clinical Experiment Pharmacology 2005;32: 273-278.

Yuan J, Xu Z, Huang C, Zhou S, Guo Y. Effect of dietary Mintrex-Zn/Mn on performance, gene expression of $\mathrm{Zn}$ transfer proteins, activities of $\mathrm{Zn} /$ $\mathrm{Mn}$ related enzymes and fecal mineral excretion in broiler chickens. Animal Feed Science Technolology 2011;168:72-79.

Zakaria, HA, Jalal M, AL-Titi HH, Souad A. Effect of sources and levels of dietary zinc on the performance, carcass traits and blood parameters of broilers. Brazilian Journal of Poultry Science 2017;19:519-526. 
